\title{
Analisis Stabilitas Lereng Tanah di Daerah Olak Alen Blitar
}

\author{
Andriyan Yulikasari, Widya Utama, Singgih Purwanto \\ Departemen Teknik Geofisika, Fakultas Teknik Sipil dan Perencanaan, Institut Teknologi Sepuluh \\ Nopember (ITS) \\ e-mail: andriyan13@mhs.geofisika.its.ac.id
}

\begin{abstract}
Abstrak-Olak Alen adalah salah satu daerah yang rawan longsor di Kabupaten Blitar. Lereng pada daerah penelitian sudah mengalami longsor sebanyak tiga kali dan hal itu terjadi ketika hujan deras. Analisis stabilitas lereng tanah dapat dilakukan menggunakan metode Bishop. Metode ini dapat memberikan gambaran kelongsoran yang terjadi pada daerah penelitian dengan prinsip kesetimbangan gaya. Pada dua keadaan yang berbeda yaitu pada keadaan kering dan keadaan jenuh air, nilai faktor keamanan lereng menunjukkan perubahan yang signifikan. Nilai faktor keamanan akan mengecil seiring dengan penambahan air ke dalam lereng tanah. Pada penelitian ini didapatkan nilai faktor keamanan lereng pada keadaan kering adalah 1.468, sedangkan nilai faktor keamanan lereng pada keadaan jenuh air adalah 1.250. Semakin kecil nilai faktor keamanan lereng tanag hingga mendekati atau lebih kecil dari 1, maka lereng tersebut berada pada keadaan yang kritis bahkan longsor.
\end{abstract}

Kata Kunci-Bishop, faktor keamanan, lereng, stabilitas.

\section{PENDAHULUAN}

$\mathrm{P}$ ENYELIDIKAN stabilitas lereng tanah selalu dilaksanakan dengan cara mengetahui faktor-faktor pengaruh dan karakteristik perilaku tanah di lereng tersebut. Salah satu faktor yang harus diperhatikan adalah pengaruh hujan yang berpotensi menyebabkan ketidakstabilan lereng. Limpasan air hujan ini akan mengisi celah atau retakan dengan material yang dapat mengubah lereng tanah akibat perbedaan karakteristik dan kekuatan gesernya. Karena adanya material yang lebih porous, material ini akan jenuh lebih cepat daripada tanah asli lereng. Kondisi ini akan meningkatkan tekanan pori positif dalam tanah dan memengaruhi stabilitas lereng secara keseluruhan.

Desa Olak Alen adalah salah satu daerah yang rawan longsor. Daerah ini terletak di lereng Gunung Butak. Topografi daerah ini sedikit curam, banyak tebing-tebing dan vegetasinya kebanyakan pohon bambu dan pohon jati. Tanah dari daerah ini terbentuk dari endapan Gunung Butak. Endapan jenis ini kebanyakan terdiri dari pasir kelanauan. Tanah pasir kelanauan adalah jenis tanah yang plastisitasnya rendah yang akan menjadi lunak ketika kadar air bertambah dan akan menjadi kering dan keras ketika kadar air rendah [1].

Metode Bishop adalah salah satu metode yang dapat digunakan untuk menganalisis kestabilan lereng. Cara analisis yang dibuat oleh A.W Bishop tahun 1955 adalah menggunakan cara elemen dimana gaya yang bekerja pada tiap elemen berlaku hukum kesetimbangan gaya. Faktor keamanan terhadap keruntuhan didefiniskan sebagai perbandingan kekuatan geser maksimum yang dimiliki tanah dibidang longsoran $\left(S_{\text {tersedia }}\right)$ dengan tahanan geser yang diperlukan untuk keseimbangan $\left(S_{\text {periu }}\right)$ [2].

\section{METODOLOGI PENELITIAN}

Lokasi penelitian ini berada di Dusun Dawung, Desa Olak Alen, Kecamatan Selorejo, Kab. Blitar pada 807'31.254" LS dan 112025'54.725" BT. Formasi batuan pada daerah penelitian adalah Formasi endapan Gunung Butak dengan batuan penyusun berupa lava, breksi gunungapi, tuff breksi dan tuff pasiran. Letak Dusun Dawung ditunjukkan dengan tanda titik merah pada gambar 1 .

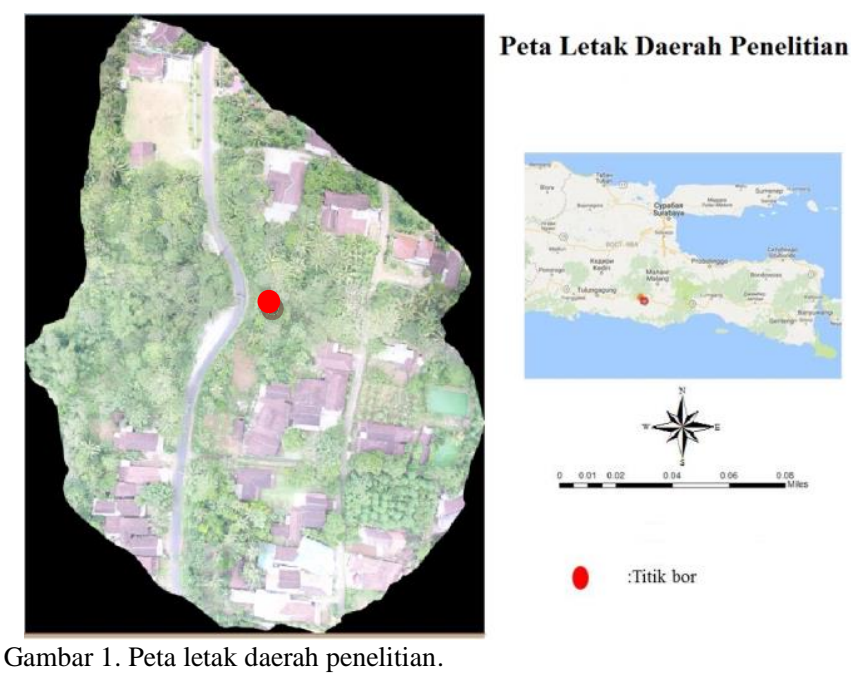

Metode pelaksanaan yang akan dilaksanakan digambarkan pada diagram alir gambar 2. Pada penelitian ini penulis menggunakan metode Bishop untuk menganalisis kestabilan lereng. Komponen- komponen yang diperlukan untuk melakukan perhitungan faktor keamanan lereng tanah adalah model lereng, data bor tanah, dan geometri lereng. lereng tanah yang menjadi studi kasus dalam penelitian ini merupakan lereng yang berasal tanah residual dengan jenis tanah pasir kelanauan. Metode Bishop mengasumsikan bidang longsor berbentuk lingkaran atau rotasi dan menghitungan nilai faktor keamanan lereng dengan metode irisan. Jadi tanah yang berada bidang longsor akan di iris-iris kemudian pada setiap irisan semua gaya yang bekerja akan dihitung berdasarkan prinsip 
kesetimbang gaya. Sedangkan persamaan yang digunakan untuk menghitung nilai faktor keamanan lereng adalah sebagai berikut:

$$
F K=\frac{\sum\left(c^{v} \mathbb{l}+\left(w_{n} \cos \alpha-\mu D\right) \tan \phi^{v}\right)}{W_{n} \sin \alpha}
$$

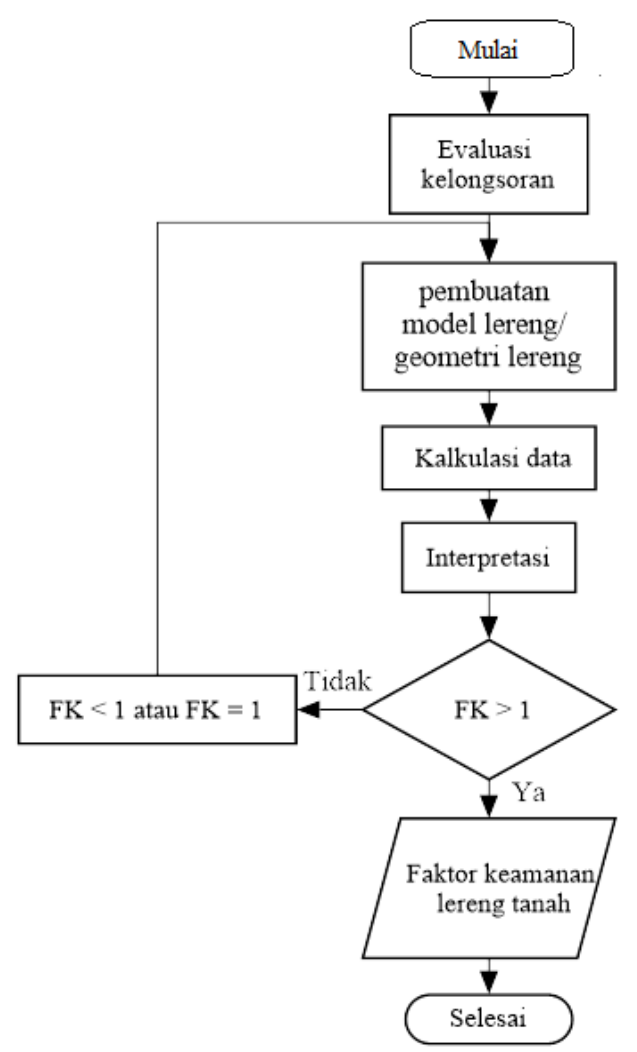

Gambar 2. Diagram alir penelitian.

\section{HASIL DAN PEMBAHASAN}

Perhitungan faktor keamanan lereng pada kondisi kering dan kondisi basah menunjukkan perubahan yang cukup drastis. Pada kondisi kering berat tanah akan menjadi lebih ringan daripada kondisi basah. Sedangkan pada kondisi basah berat isi tanah akan menjadi bertambah besar karena adanya penambahan air hujan yang mengalir ke dalam lereng melalui retakan di permukaan lereng. Penambahan beban ini akan menyebabkan naiknya muka air tanah dan akan membuat tekanan efektif tanah menjadi rendah. Seiring dengan menurunnya tekanan efektif tanah, kekuatan geser tanah juga akan mengalami penurunan. Hal inilah yang menyebabkan kestabilan lereng akan menjadi mendekati kritis ketika terjadi hujan.

Hasil perhitungan faktor keamanan lereng pada gambar 3 dan gambar 4 juga menunjukkan hal serupa, yaitu nilai faktor keamanan lereng pada kondisi basah mendekati nilai kritis lereng. Pada kondisi kering nilai faktor kemanan lereng adalah 1.468, sedangkan pada kondisi basah memiliki nilai 1.250. Lereng akan dikatakan stabil apabila nilai faktor keamanannya melebihi 1. Sehingga pada dua kondisi ini lereng tanah pada daerah penelitian masih dikategorikan aman dan tidak mengalami kelongsoran.

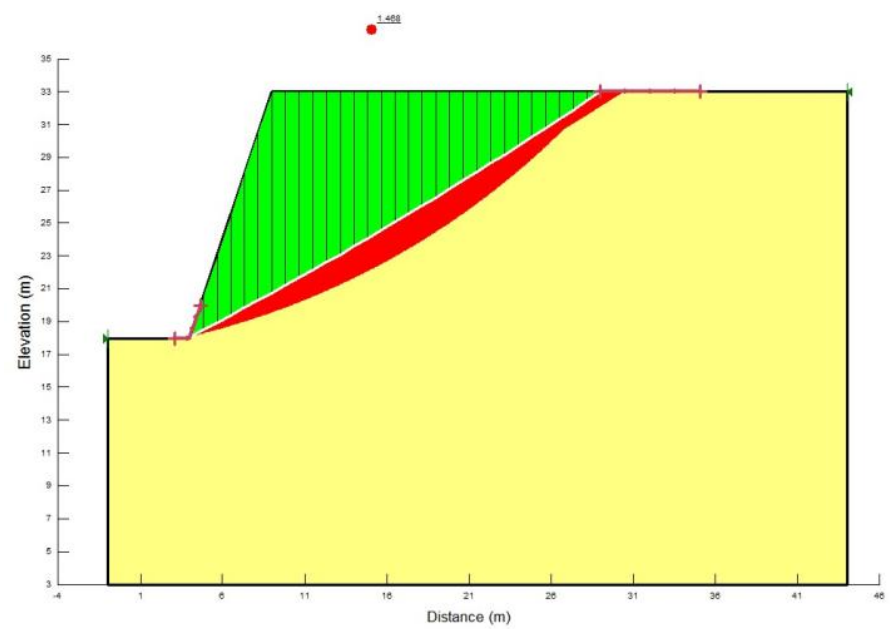

Gambar 3. Hasil perhitungan nilai FK pada kondisi kering.

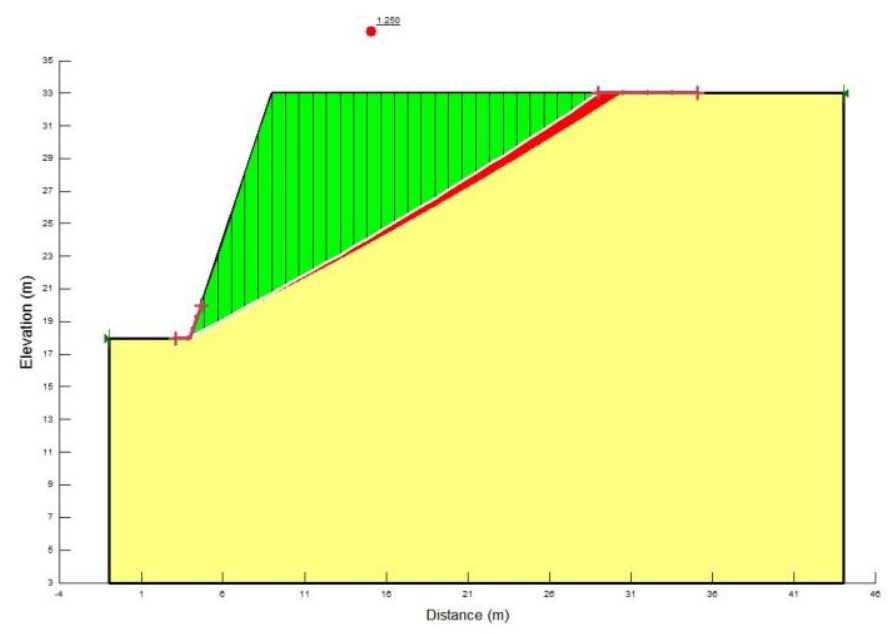

Gambar 4. Hasil perhitungan nilai FK pada kondisi basah.

\section{KESIMPULAN/RINGKASAN}

Berdasarkan pembahasan diatas maka dapat disimpulkan bahwa hujan akan membuat lereng tanah menjadi tidak stabil karena akan menurunkan tekanan efektif tanah yang mengakibatkan kekuatan geser tanah berkurang. Pada peneilitian ini ketidakstabilan itu dibuktikan dengan nilai faktor kemanan lereng tanah yang semakin mendekati nilai kritis yaitu 1 pada konsisi basah. Saran untuk penelitian selanjutnya yaitu perlu diperhatikan keadaan muka air tanah daerah penelitian karena tanah daerah penelitian merupakan jenis tanah residual yang dimana muka air tanahnya berada pada kedalaman yang sangat dalam, dalam hal ini lebih dari 20 meter maka perhitungan tekanan air pori tidak diperlukan namun perlu juga untuk menghitung rembesa air hujan yang terjadi pada lereng dan perhitungan beban seperti beban bangunan, kendaraan dan juga pohon mengingat daerah penelitian yang berada di pinggir jalan raya. 
DAFTAR PUSTAKA

[1] L. D. Wesley, Mekanika Tanah untuk Tanah Endapan dan Residu. Yogyakarta: Andi, 2012.

[2] Susi dan Yohan, "Program Analisis Stabilitas Lereng," Universitas Diponegoro, 2007. 